\section{EXATAS E TECNOLÓGICAS}

V.4 • N.1 2020 - Fluxo Contínuo

ISSN Digital: 2359-4942

ISSN Impresso: 2359-4934

DOI: $10.17564 / 2359-4942.2020 v 4 n 1 p 88-100$
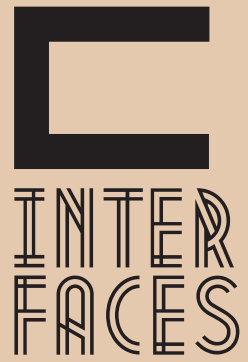

CIENTÍFICAS

\title{
ESTUDO PRELIMINAR PARA IMPLANTAÇ̃̃O DE UM JARDIM BOTÂNICO NO BAIRRO DO BENEDITO BENTES EM MACEIÓ/AL
}

PRELIMINARY STUDY FOR THE IMPLEMENTATION OF A BOTANICAL GARDEN IN BENEDITO BENTES MACEIÓ/AL

ESTUDIO PRELIMINAR PARA LA IMPLEMENTACIÓN DE UN JARDÍN BOTÁNICO EN EL BARRIO BENEDITO BENTES EN MACEIÓ/AL

Jamerson Calheiros da Silveira Silva Melissa Mota Alcides ${ }^{2}$

\section{RESUMO}

Os jardins botânicos são instituições que agrupam coleções documentadas de plantas vivas para fins de pesquisa, conservação, exposição e instrução científica. Quando se fala em educação ambiental deve-se pensar em ir além de estudos teóricos em sala de aula, pois a aprendizagem prática auxilia as pessoas a conhecer o seu lugar no ecossistema e entender que os seus atos podem causar efeitos ou consequências nocivas ao meio ambiente. Este trabalho final de graduação teve como objetivo geral propor a implantação de um jardim botânico no bairro do Benedito Bentes, localizado na parte alta da cidade de Maceió. 0 bairro é bastante populoso e carece de espaços destinados ao público em geral, de forma que possibilite a população de desfrutarem de espaços abertos, com áreas verdes ao ar livre, que estimulam o convívio entre seus usuários, a prática de exercícios físicos e a contemplação e uso do espaço urbano. 0 conceito para este trabaIho foi baseado nas orquídeas alagoanas, uma das maiores famílias de espécies vegetais existentes, que apresentam muitíssimas e variadas formas, cores e tamanhos, sua principal característica a rápida adaptabilidade a novos ambientes.

\section{PALAVRAS-CHAVE}

Turismo, Espaço Público, Jardim Botânico, Orquídeas Alagoanas. 


\section{ABSTRACT}

Botanical gardens are institutions that group documented collections of living plants for research, conservation, exhibition and scientific instruction. When talking about environmental education one should think about going beyond theoretical studies in the classroom, because practical learning helps people know their place in the ecosystem and understand that their acts can cause harmful effects or consequences to the environment Environment. This final undergraduate work aimed at proposing the implementation of a botanical garden in the BeneditoBentes neighborhood, located in the upper part of the city of Maceió. The neighborhood is very populous and lacks spaces for the general public, so that it enables the population to enjoy open spaces, with green outdoor areas, which stimulate the coexistence between its users, the practice of physical exercises and the contemplation and use of urban space. The concept for this work was based on alagoas orchids, one of the largest families of existing plant species, which present many and varied shapes, colors and sizes, its main characteristic the rapid adaptability to new environments.

\section{KEYWORDS}

Tourism. Public Space. Botanical Garden. Orchids of Alagoas.

\section{RESUMEN}

Los jardines botánicos son instituciones que agrupan colecciones documentadas de plantas vivas con fines de investigación, conservación, exhibición e instrucción científica. Cuando se habla de educación ambiental, se debe pensar en ir más allá de los estudios teóricos en el aula, ya que el aprendizaje práctico ayuda a las personas a conocer su lugar en el ecosistema y comprender que sus acciones pueden causar efectos nocivos o consecuencias para el medio ambiente. Este trabajo final de graduación tenía el objetivo general de proponer la implantación de un jardín botánico en el barrio Benedito Bentes, ubicado en la parte alta de la ciudad de Maceió. El barrio es muy populoso y carece de espacios destinados al público en general, a fin de que la población pueda disfrutar de espacios abiertos, con áreas verdes al aire libre, que fomentan la socialización entre sus usuarios, la práctica de ejercicios físicos y la contemplación. y uso del espacio urbano. El concepto para este trabajo se basó en las orquídeas de Alagoas, una de las familias más grandes de especies de plantas existentes, que tienen muchas y variadas formas, colores y tamaños, su característica principal es la rápida adaptabilidad a nuevos entornos.

\section{PALABRAS CLAVE}

Turismo, Espacio Público, Jardín Botánico, Orquídeas Alagoas. 


\section{INTRODUÇ̄̃̃O}

Na cidade de Maceió a visitação turística fica limitada aos bairros da área litorânea, onde situa-se a orla marítima, pois o município não oferece aos seus visitantes outros espaços públicos que possam ser explorados. Diante disso, o presente Trabalho Final de Graduação propôs a implantação de um Jardim Botânico situado no bairro do Benedito Bentes, parte alta da cidade.

0 terreno escolhido para a implantação do estudo fica localizado às margens da principal avenida de entrada do bairro, a Av. Cachoeira do Meirim. 0 terreno localiza-se próximo ao terminal rodoviário, a estabelecimentos comerciais locais e aos novos conjuntos residenciais, o dotando de visibilidade. Também existem na área as duas principais escolas de ensino público da região; a Escola Marcos Antônio Cavalcante e o Instituto Federal de Alagoas (IFAL).

Acredita-se que o bairro possui viabilidade para a implantação do Jardim Botânico e pode atrair inclusive turistas para a sua visitação, como pode ser observado em outras cidades brasileiras, como no caso de Curitiba que teve a implantação de um jardim botânico em 1991 e se tornou o maior ponto turístico da cidade.

O mesmo ocorreu com o Jardim Botânico Plantarum, no estado de São Paulo, na cidade de Nova Odessa, onde ele fica localizado, que além de se tornar um atrativo turístico, também é um grande centro de referência em pesquisa e conservação da flora brasileira. Outro exemplo é o Jardim Botânico de Ihontin em Minas Gerais, com seu vasto número de espécies é caracterizado como o possuidor da maior coleção em números de espécies de plantas vivas entre os jardins botânicos brasileiros.

A metodologia adotada para a elaboração do programa de necessidades levou em conta as informações disponibilizadas pela Rede Brasileira de Jardins Botânicos (RBJB) e o Conselho Nacional do Meio Ambiente (CONAMA) que auxiliaram na compreensão dos conceitos, dos elementos e dos critérios que compõem a estrutura e implantação dos jardins botânicos. Também foram realizados estudos de casos, como por exemplo o Jardim Botânico de Curitiba, o de Inhotim e o Jardim Botânico Plantarum que serviram como referência para o projeto. A caracterização e diagnóstico da área de estudo foram realizadas a partir do levantamento de dados via ferramentas digitais, como Google Earth e Street View e visitas de campo.

\section{DIRETRIZES PARA IMPLANTAÇÃO DE UM JARDIM BOTÂNICO}

Existem dois documentos colaborativos para a criação e implantação de Jardins Botânicos no Brasil, produzidos pela RBJB e pelo CONAMA, ambos dispõem sobre a criação, normatização e o funcionamento dos jardins botânicos e foram seguidas para a concepção do projeto.

A resolução do CONAMA, n 339 , de 25 de setembro de 2003, define os objetivos que os jardins botânicos deverão possuir: promover a pesquisa, educação, preservação e lazer, compatibilizando ao interesse do estudo das plantas; proteger as espécies ameaçadas; reabilitando o ecossistema local; manter um acervo para fins de pesquisa e estudo; e, promover intercambio cientifico, técnico e cultural com entidades e órgãos nacionais e estrangeiros. 
Já a Rede Brasileira de Jardim Botânico define que o local que abrigar um jardim botânico deve ser definido em conformidade com um plano de manejo para esta área. Ele deve possuir um quadro técnico-científico, serviços de vigilância e jardinagem, além de uma área para produção de mudas.

O planejamento físico ideal para a implantação do mesmo deve observar a paisagem local, as condições especiais de relevo, cursos d'agua naturais e artificiais, áreas naturais remanescentes e a integração com o entorno. Já as coleções devem possuir um local para exposição e armazenamento adequado e sistema de tombamento e documentação do acervo. O quadro de funcionários deve possuir botânicos, ecólogos, biólogos, agrônomos, horticultores, arquitetos, jardineiros, educadores e administradores.

\section{CARACTERIZAÇ̃̃O E DIAGNÓSTICO DA ÁREA DE ESTUDO}

Como o foco do projeto é expandir a área turística do município de Maceió para parte alta da cidade, a escolha da área se deu a partir da identificação de um local na parte alta da cidade, em um terreno atualmente sem uso (FIGURA 1). Foram levantadas as potencialidades do local como a existência de vias de fácil acesso e ligação, grande fluxo de pessoas, proximidade a residências e conjuntos habitacionais além de escolas, shopping e estabelecimentos comerciais.

Figura 1 - Recorte da Área

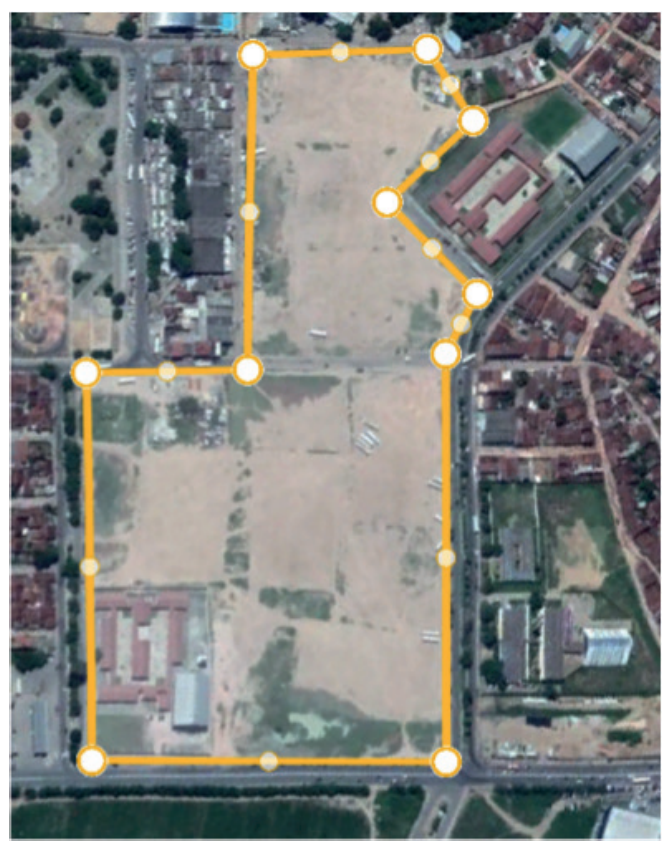

Fonte: Google Earth (2019). 
Com relação ao uso e ocupação do solo, pode-se observar que no entorno do terreno predomina o uso residencial e alguns pontos comerciais importantes, como o restaurante popular, o supermercado GBarbosa e um posto de combustível, por se tratarem de locais de fácil acesso aos visitantes, na parte posterior do terreno encontra-se o Pronto Socorro Denilma Bulhões, que atende os moradores da região.

A região é carente de mobiliário urbano, tendo próximo ao terreno a Praça Padre Cicero que encontra-se em estado de calamidade, todo seu mobiliário está danificado, podendo gerar acidentes nos usuários. Embora esteja nesta situação é utilizada pela população, por ser única nas proximidades.

Figura 2 - Esquema de uso e ocupação do solo

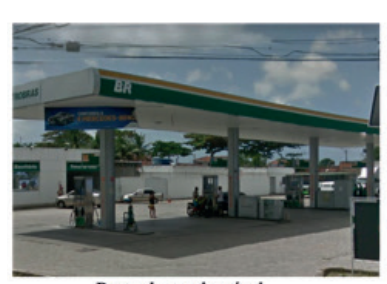

Posto de combustivel
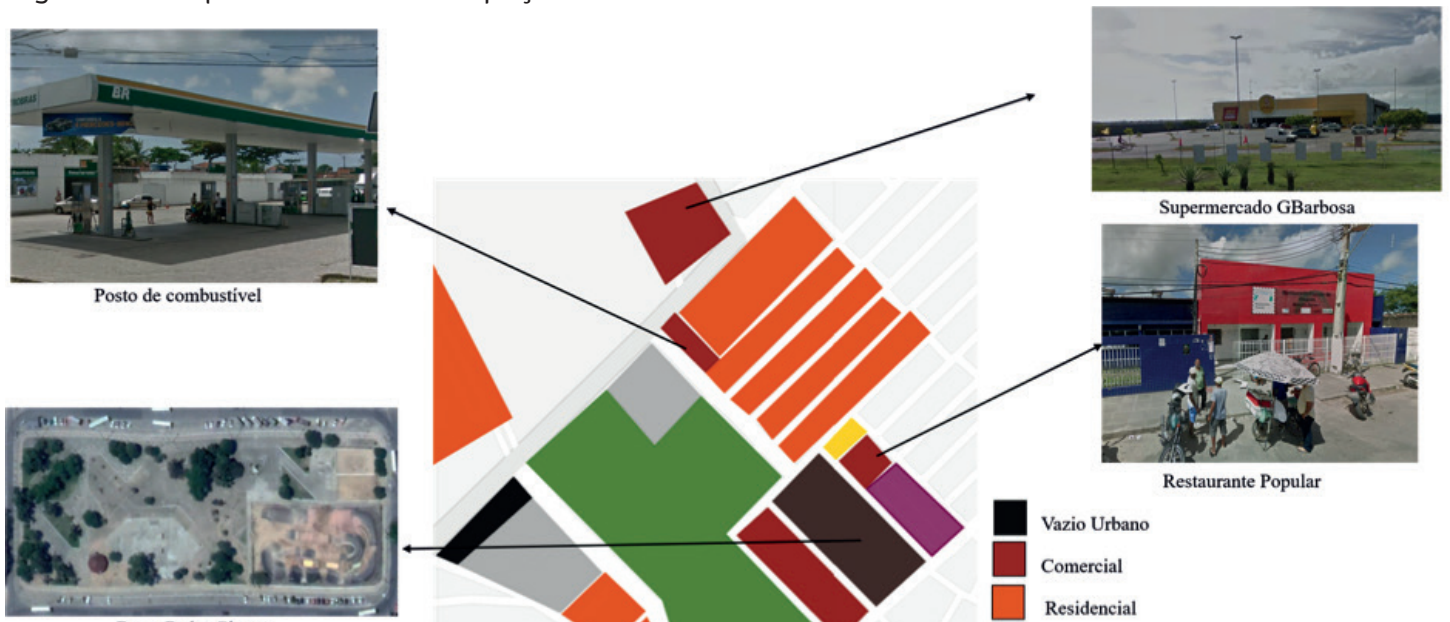

Praça Padre Cícero
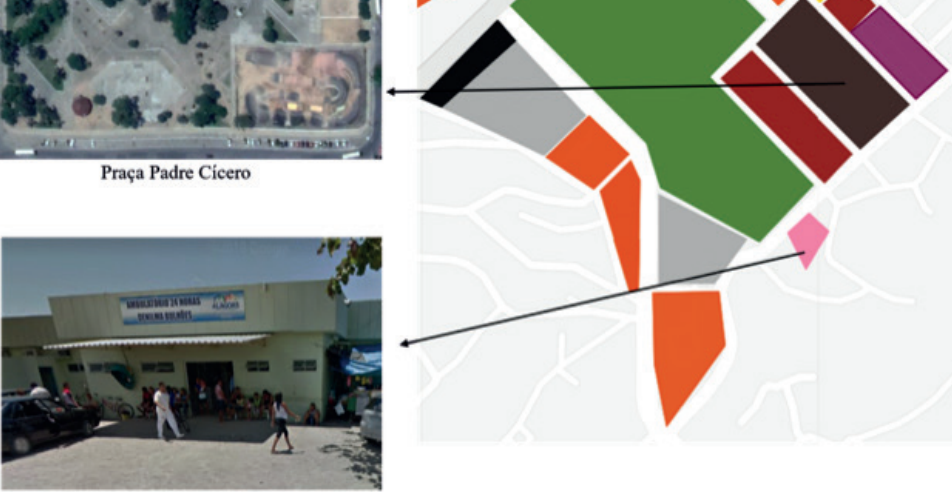

$\square$ Vazio Urbano
$\square$ Comercial
$\square$ Residencial

Restaurante Popular

$\square$ Fórum Regional do Benedito Bentes .

Terminal de Ônibus

Praça Padre Cícero

D Área de Estudo

$\square$ Pronto Socorro Denilma Bulhões

Educacional

Pronto Socorro Denilma Bulhões

Fonte: Produzido pelo autor (2019).

Com relação à legislação, a área de intervenção está inserida na Zona Residencial III (ZR -III), segundo o Código de Urbanismo e Edificações de Maceió “é a área na cidade destinada à ocupação predominante do uso residencial”. Deve-se observar, também, as seguintes diretrizes: verticalização baixa; possibilidade de implantação de atividades comerciais, de serviços e indústrias até o grupo IV, compatibilizadas ao uso residencial, sem prejuízo da avaliação dos impactos ambientais e urbanos e por último, estímulo à promoção de habitação de interesse social. 


\section{PROPOSTA PROJETUAL DO JARDIM BOTÂNICO ALAGOENSIS}

A criação do Jardim Botânico teve seu conceito baseado nas orquídeas alagoanas, uma das maiores famílias de espécies vegetais existentes, que apresentam muitíssimas e variadas formas, cores e tamanhos. Como meio de chamar a atenção dos visitantes e apresentar aos mesmos as orquídeas do Estado, toma-se como partido as formas e cores das flores que serão usadas nos jardins e os caminhos foram inspirados no emaranhado das raízes.

Figura 3 - Planta baixa humanizada do jardim botânico alagoensis

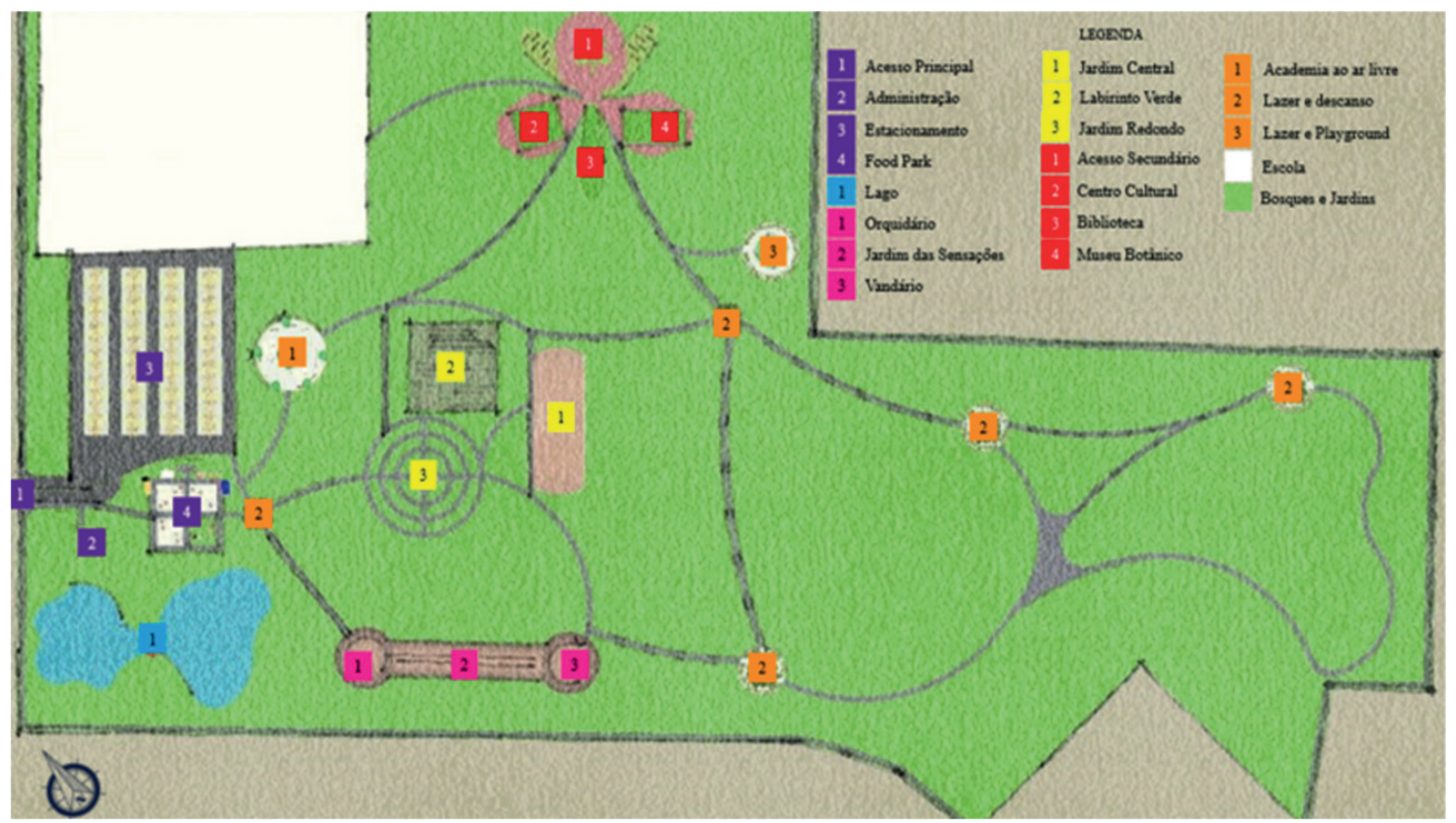

Fonte: Produzido pelo autor (2019).

A entrada principal foi pensada de uma forma que deixasse o visitante curioso para entrar no espaço, os ipês foram dispostos no bosque da entrada por suas cores vivas e convidativas, todo 0 jardim foi cercado por grades de ferro, que deixam o interior a amostra para quem está passando pelo entorno, convidando assim a conhecer o mesmo. 0 acesso dos automóveis é guiado pelo porteiro que fica na guarita do jardim, os pedestres e carros têm acesso livre assim que fazem seu cadastro com o porteiro, para controle de entrada e saída. 

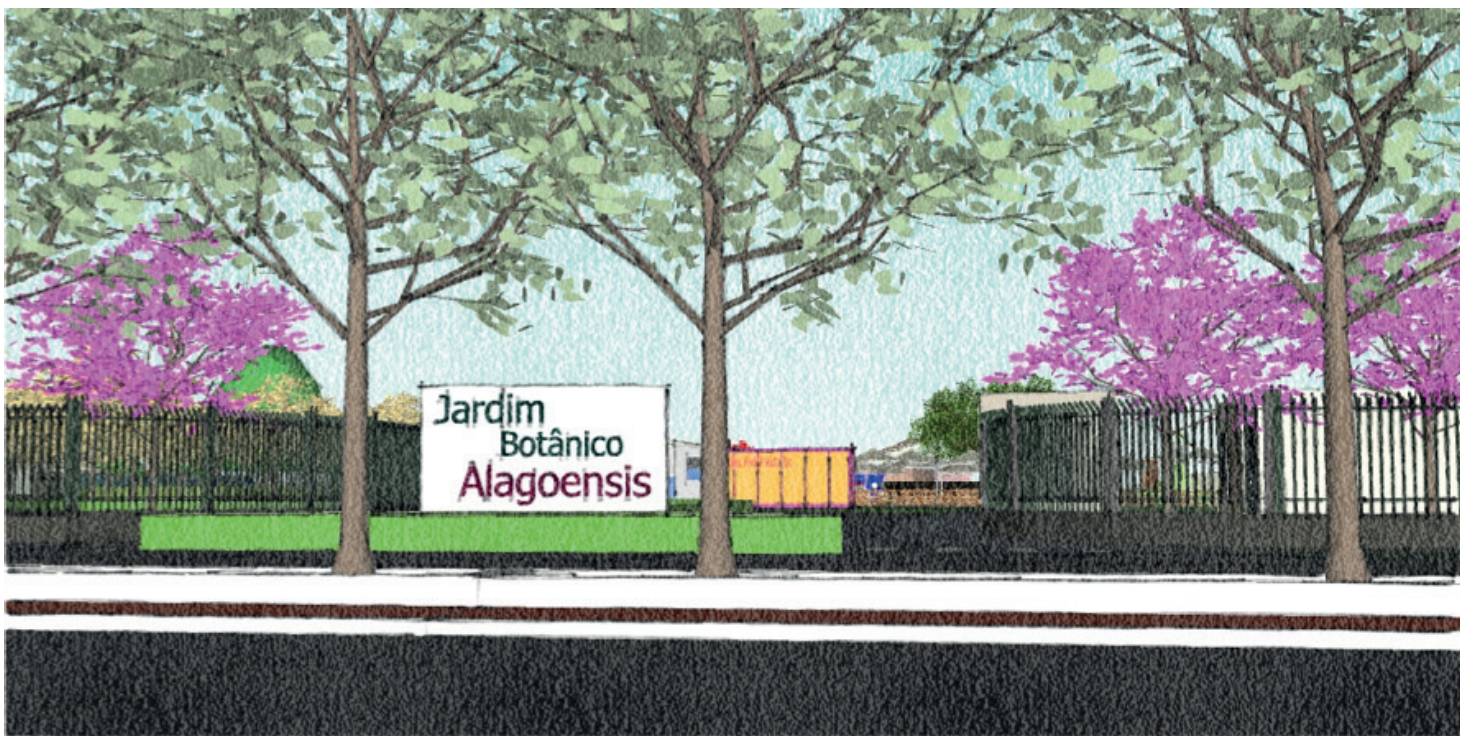

Fonte: Produzido pelo autor (2019).

Assim que o pedestre entra ele encontra a administração do jardim, que serve de base para todo o funcionamento dele. Nela foi disposta a recepção do jardim, sala do administrador, sala de reuniões e a sala de vídeo monitoramento. A administração tem estrutura de alvenaria convencional, com coberta verde e grandes janelas de vidros. A energia que alimenta o prédio é energia solar, que é capturada por placas solares dispostas em sua coberta. As grandes janelas de vidro, servem para quebrar a rotina de trabalho dos funcionários, lhes dando uma vista do jardim, podendo além de ver a movimentação, apreciar o ambiente externo.

Em frente à guarita e administração, foi disposto do estacionamento, composto por 5 ruas de acesso às vagas, que somam 208 vagas, onde dessas, 12 vagas são exclusivas para idosos, 5 vagas exclusivas para PCD3, de acordo com as Leis Federais 10.048 e 10.098, ambas do ano de 2000, regulamentadas pelo Decreto Federal no 5.296/2004. O piso do estacionamento foi feito com asfalto drenante e as vagas têm piso intertravado com grama, assim todo o estacionamento é permeável, não acumulando água e evitando enchentes no jardim.

0 ponto de encontro é o Food Park, onde se encontram trailers de comidas e bebidas, além de lojas de souvenires. Uma área ao ar livre que permite que os visitantes façam suas refeições, contemplando a paisagem do jardim. No local também foi implantado um playground, para as crianças se divertirem, 0 playground é rodeado por arbustos que não permitem que as crianças saiam a não ser pelo local certo, que está em frente às mesas do food Park, assim os pais podem ficar despreocupados. Também é onde fica o bloco de banheiros, disposto por trás dos trailers, deixando a área mais intimista e reservada.

3 PCD - Pessoas com necessidades Especiais, pessoas com deficiência física. 
Ao lado do Food Park encontra-se o lago, um local calmo e de contemplação, onde foram dispostos mesas e bancos de piqueniques, para as famílias se reunirem. 0 lago contará com peixes ornamentais e no centro dele haverá um palco de eventos, onde poderão ser realizados diversos tipos de comemorações, este palco será construido com madeira de reflorestamento.

Umas das partes mais lúdicas e divertidas do jardim é o labirinto verde, com arbustos que chegam a uma altura de 2,0m, o labirinto desafia quem gosta de aventura, com $1.100 \mathrm{~m}^{2}$ de caminhos. 0 visitante não precisará procurar a saída, o espaço é apenas para ter a sensação de estar dentro de um labirinto, pois o caminho é único e só leva a um lugar, pelo fato de só existir uma entrada e uma saída.

A estufa central foi projetada para se adequar às condições climáticas do estado de Alagoas, não seria possível projetar algo em vedação de vidros e totalmente fechado, como uma estufa deve ser, então a solução encontrada foi um jardim central (FIGURA 5) que terá sua estrutura em treliças de madeiras de reflorestamento, assim o ar poderá circular pelo espaço, as plantas receberão a iluminação adequada e estarão em ótimas condições.

A coberta tem um lado aberto, que é o lado do poente, pois permitirá que o sol entre com mais força no jardim, para as plantas que precisam de luz do sol direta, a outra parte fechada ficará as plantas de precisam de iluminação indireta, o lago central do jardim, funcionará como umidificador do ar, pois como terão orquídeas resgatadas de extração ilegal, elas precisarão de muita umidade.

A vegetação do jardim central, será exclusivamente de plantas nativas de Alagoas, onde os visitantes poderão conhecer essas espécies, as orquídeas alagoanas que estarão no jardim central são fascinantes pelos seus minúsculos tamanhos, o que chama a atenção das pessoas que não conhecem sobre elas.

Figura 5 - Proposta do jardim central

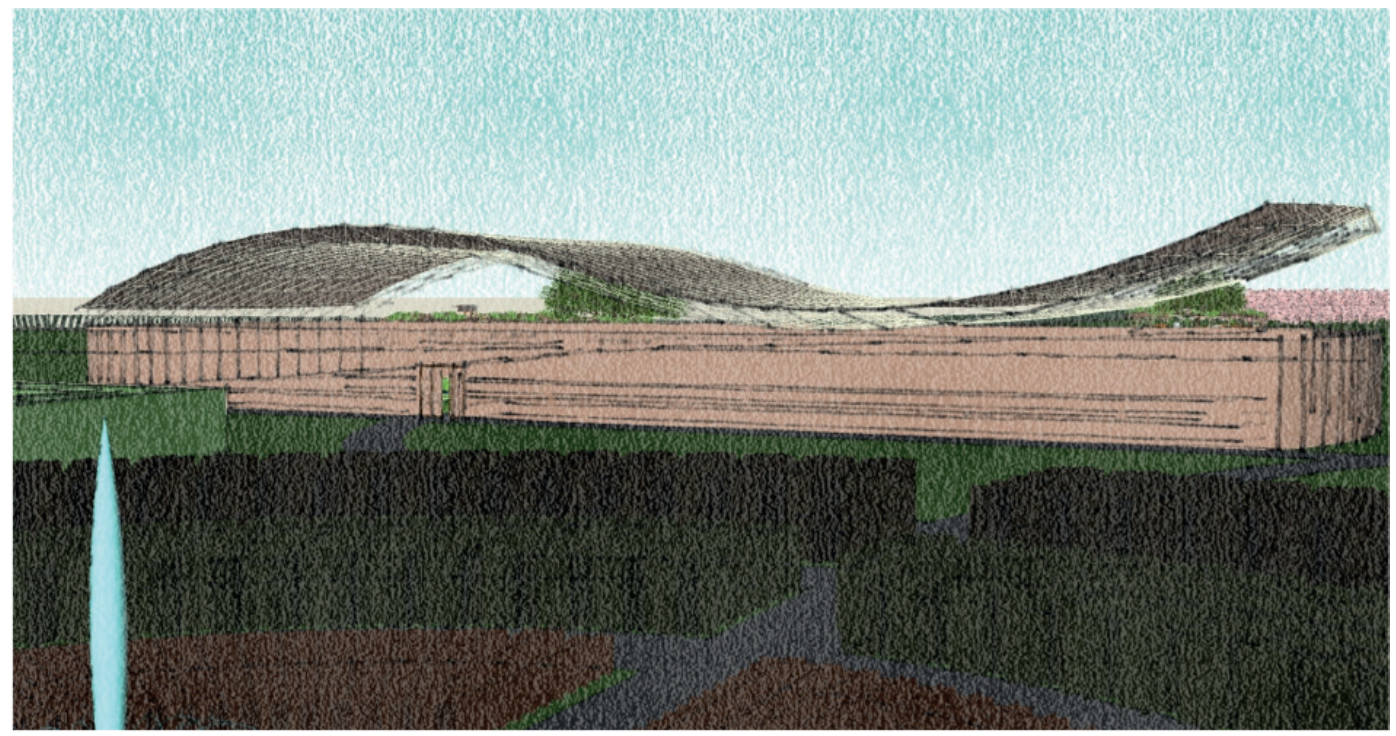

Fonte: Produzido pelo autor (2019). 
Com a mesma estrutura do jardim central, foi projetado o bloco das sensações (FIGURA 6), composto pelo Orquidário, Jardim das Sensações e o Vandário. Um bloco que trará uma experiência sensorial aos visitantes, iniciando pelo orquidário, o visitante terá o prazer de conhecer diversos tipos de orquídeas, não somente as alagoanas, como no jardim central, mas várias espécies, o orquidário possui uma fonte em seu centro, as orquídeas gostam de ambientes com uma grande umidade.

Ao retirar-se do orquidário o visitante entra no corredor das sensações, um jardim que aguçará todos os seus meios sensoriais, é aconselhado entrar descalço para sentir nos pés os diversos tipos de pisos, as pessoas poderão sentir no tato as texturas das plantas, sentir o cheiro que elas exalam, ouvir o som das fontes e pássaros, nesse ambiente também se encontra um borboletário.

Logo assim que sair do corredor o visitante entra no Vandário, onde localiza-se as orquídeas Vandas, que não são nativas brasileiras, mas se adaptaram ao clima do país. 0 último bloco também possui uma fonte em seu centro, pois mais do que qualquer outra orquídea, as Vandas necessitam de umidade, por que suas raízes são aéreas, sem nenhuma fonte de armazenamento de água. Foi no emaranhado de suas raízes que os caminhos do Jardim Botânico Alagoensis (JBA) foram inspirados.

Figura 6 - Bloco das sensações: Orquidário, Jardim das Sensações e Vandário

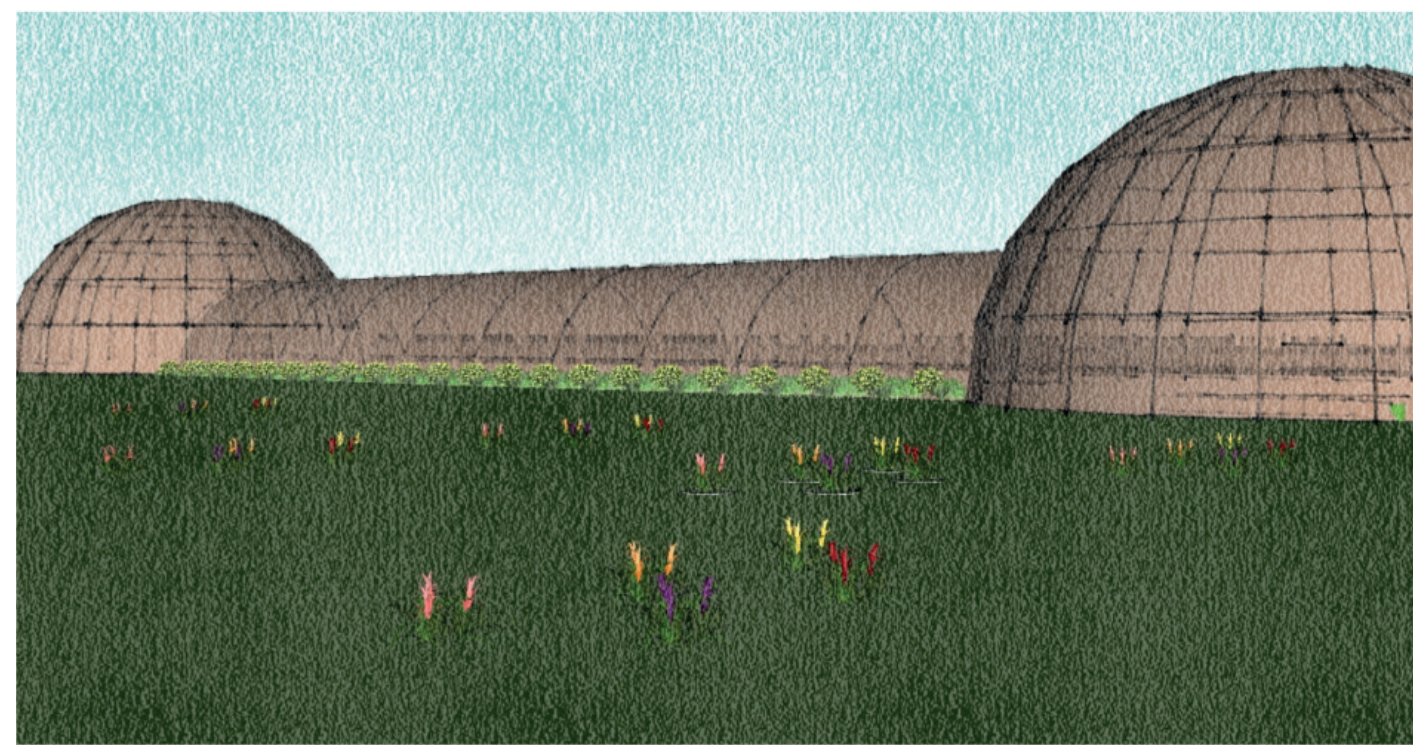

Fonte: Produzido pelo autor (2019).

O Jardim Botânico Alagoensis conta com uma entrada secundária (FIGURA 15) que será a entrada principal para os alunos da Escola Estadual de Ensino Integral Marcos Antônio Cavalcante Silva, localizada dentro do terreno do jardim. Essa entrada não será exclusiva para os alunos e funcionários da escola, mas também será aberta aos visitantes que já tiverem cadastro efetuado para entrar no jardim. 
A partir da entrada secundária temos o jardim que dá acesso ao bloco educacional, este foi projetado para atender aos visitantes e alunos, o jardim é bem florido e tem bancos de madeira ecológica, bem arborizado e aconchegante que induzirá a pessoa a permanecer no lugar. O bloco educacional é um espaço voltado à cultura e educação, nele encontramos três edificações, o Museu botânico, a Biblioteca central e o Centro Cultural.

O Museu Botânico Alagoensis conta com uma estrutura de armazenamento e coleta de dados da área botânica do jardim, nele encontra-se o Herbário que terá capacidade para armazenar até 50.000 amostras de vegetais desidratadas. Além dessas, muitos outros elementos de origem vegetal irão também fazer parte do herbário, como por exemplo fragmentos de madeira, frutos, artefatos, lâminas com cortes anatômicos e pólen ou mesmo amostras de DNA.

No museu também será encontrado o Banco de Germoplasma, que buscará conservar informação genética representativa da alta diversidade da flora brasileira, sendo um registro histórico da variação vegetal, uma base para a conservação e para a biotecnologia. O banco é uma sala refrigerada para conservar essas amostras, que tem temperatura que varia de $1{ }^{\circ} \mathrm{C}$ até $-20^{\circ} \mathrm{C}$, os funcionários precisarão de roupas especiais para entrar no banco e guardar ou recolher amostras.

Ele também conta com uma galeria de artes e exposições, onde serão realizadas amostras de artes e cultura do estado. Terá uma galeria de exposição permanente de artistas alagoanos, que poderão se cadastrar e deixar uma obra de artes na galeria. Também terá exposições temporárias, onde o museu abre suas portas para artistas de outros estados e até países, para que eles usem o espaço, mostrando sua arte.

A Biblioteca Central Alagoensis contará com um grande acervo de livros, que dará suporte aos alunos da Escola Estadual de Ensino Integral Marcos Antônio Cavalcante Silva, eles poderão usar a biblioteca e mediante cadastro levar os livros para estudar em casa, nela terá computadores para uso dos alunos.

Esse bloco é um dos mais importantes para escola, pois ela não possui biblioteca em seu prédio, então ajudará muito nos estudos dos alunos. A biblioteca é o principal meio de acesso gratuito ao livro, assim ajudará os alunos a aumentar seus níveis de conhecimento e competência em leitura.

O Centro Cultural Alagoensis (FIGURA 19) foi pensado para que os jovens da região tivessem uma rota de fuga da violência, neste espaço eles poderão realizar aulas de dança, participar de cursos e workshops, assistirem filmes, pois o espaço contará com uma sala de cinema e atividades culturais.

O bloco contará com 8 salas, divididas em salas de dança, de cinema, dos professores e coordenação, além do auditório. Os visitantes também poderão usar o espaço, pois semanalmente será divulgada as atividades que serão desenvolvidas durante a semana, assim todo dia o bloco realizará algo diferente, induzindo os visitantes a frequentarem o espaço por mais dias.

As três construções do bloco educacional, serão edificadas em alvenaria convencional, que não precisa de mão de obra especializada, seu teto será verde para reduzir a incidência de calor no interior, embora não seja grande pelo fato de estar em meio a árvores.

Foi necessário alterar a fachada da escola (FIGURA 20) para que ela se incluísse no jardim, pois estava em estado degradável. Foi colocado um bicicletário em sua frente, que foi um pedido dos alunos, que iam de bicicleta e tinham que deixá-la jogada no interior da escola. Em frente a ela será disposto o jardim educacional onde os alunos poderão participar da plantação de mudas do JBA, terão aulas de botânico e jardinagem. 
Estas são as propostas desenvolvidas para a Implantação do Jardim Botânico Alagoensis, projeto simples desenvolvido para as condições de Alagoas, como forma de ampliar o turismo do Estado e adquirir um meio de ajudar a garantir o futuro botânico alagoense. Foram usados materiais simples, muitos deles reaproveitáveis, como a madeira ecológica, de mão de obra barata e não especializada.

0 jardim ainda dará todo suporte educacional à escola que se encontra em sua área de implantação, entende-se que a presença de um jardim botânico no município de Maceió seria de grande valor não apenas para a conservação das espécies que se encontram em risco de extinção, como também para à sensibilização da coletividade sobre as questões ambientais e à sua organização e participação na defesa da qualidade do meio ambiente.

\section{CONCLUSÃO}

A motivação para este estudo surgiu do questionamento sobre a falta de espaços públicos para o lazer e entretenimento na cidade, para além da orla, quando encontramos, geralmente são praças em mau estado de conservação. Com a implantação de um jardim botânico, o Estado pode ampliar sua área de turismo, levando visitantes para o planalto da cidade.

A principal contribuição deste trabalho visa atender a criação de um espaço público de qualidade para a população, aliado ao caráter da preservação ambiental e a ampliação dos pontos turísticos de Alagoas, tema muito importante e discutido na atualidade.

O jardim botânico, enquanto instituição, é um dos patrimônios ambientais que possui grande importância como centro de informação da flora e estudos de botânica. É um museu a céu aberto, no qual seu conjunto arquitetônico, de construções espalhadas pela área do jardim, pode fazer deste um atrativo mais interessante aos olhos de estudantes e apreciadores de cultura e história, além dos próprios frequentadores e visitantes da área.

Portanto, conclui-se que o objetivo do projeto foi alcançado visto que foi apresentada uma solução de projeto, o qual demostra não só os benefícios da criação de um jardim botânico, como elemento incentivador de cultura, pesquisa e turismo, mas também como elemento arquitetônico para a cidade, demostrando assim, os resultados de um trabalho conjunto com arquitetos, urbanistas, paisagistas e outros.

Dito isso, percebe-se claramente a importância que o arquiteto urbanista pode desempenhar para a cidade, cumprindo uma função social, ambiental e cultural. Fica aqui, uma pequena opção de desenho apresentado, como forma de atender as necessidades locais, que poderão ser estudadas e aprofundadas com o passar do tempo.

\section{REFERÊNCIAS}

BARCELLOS, Daniel Câmara. Uma viagem pela história dos jardins. 2017. Disponível em: http:// www.jardimdeflores.com.br/paisagismo/a05daniel.htm. Acesso em: 22 maio 2019.

CONAMA - Conselho Nacional do Meio Ambiente. Resolução n. 339, de 25 de setembro de 
2003. Dispõe sobre a criação, normatização e o funcionamento dos jardins botânicos e dá outras providências. Brasília, DF, 26 dez. 2001. Seção 1. p.97.

COSTA, T. S. Os jardins botânicos brasileiros - Desafios e Potencialidades. Revista Ciência e Cultura, São Paulo, v. 62, n. 1, 2010. Disponível em: http://cienciaecultura.bvs.br/scielo. php?script=sci_arttext\&pid=S0009-67252010000100010. Acesso em: 22 maio 2019.

IBGE - Instituto Brasileiro de Geografia e Estatística. Maceió, 2017. Disponível em: https://cidades. ibge.gov.br/brasil/al/maceio/panorama. Acesso em: 8 nov. 2019.

PANZINI, Franco. Projetar a natureza: Arquitetura da paisagem e dos jardins desde as origens até a época contemporânea. São Paulo: Editora Senac São Paulo, 2013.

RDBJ - Rede Brasileira de Jardins Botânicos. Diretório dos jardins botânicos brasileiros. Rio de Janeiro: Expressão e Cultura, 2000. Disponível em: https://docplayer.com.br/5623007-Redebrasileira-de-jardins-botanicos-documento-colaborativo-oficial-para-criacao-e-implantacao-dejardins-botanicos-conteudo-1.html. Acesso em: 9 abr. 2019.

RIBEIRO, R. M.; SILVEIRA, M. A. T. Planejamento urbano, lazer e turismo: os parques públicos em Curitiba-PR. Revista Turismo - Visão e Ação, v. 8, n. 2, p. 309-321, maio/ago. 2006. Disponível em: https://siaiap32.univali.br/seer/index.php/rtva/article/view/293/254. Acesso em: 5 maio 2019.

SANJAD, Nelson. Os jardins botânicos luso-brasileiros. Revista Ciência e Cultura, São Paulo, v. 62, n. 1, p.20-22, 2010. Disponível em: http://cienciaecultura.bvs.br/scielo.php?script=sci_arttext๕pid =S0009-67252010000100009. Acesso em: 8 abr. 2019.

SEGAWA, H. Ao amor do público: jardins no Brasil. São Paulo: Studio Nobel: FAPESP, 1996.

VIEIRA, Maria Elena. 0 jardim e a paisagem. São Paulo: Annablume,2007. Disponível em: http:// paisagismo-brasil.blogspot.com/2015/12/jardins-medievais.html. Acesso em: 18 ago. 2019. 
1 Arquiteto e Urbanista, egresso do curso de Arquitetura e Urbanismo da UNIT/AL. E-mail: jamerson.arquitetura@gmail.com

2 Mestre; Professora do curso de Arquitetura da UNIT/AL. E-mail: motamelissa@yahoo.com.br

\section{(@) (1) (-)}

Este artigo é licenciado na modalidade acesso abertosob a Atribuição-Compartilhalgual CC BY-SA

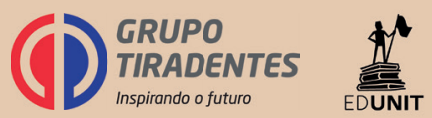

